\title{
Preplant 1,3-D treatments test well for perennial crop nurseries, but challenges remain
}

\author{
by Bradley D. Hanson, Suduan Gao, James \\ Gerik, Ruijun Qin, J. Alfonso Cabrera, Amit \\ J. Jhala, M. Joy M. Abit, David Cox, Brian \\ Correiar, Dong Wang and Gregory T. Browne
}

\section{Preplant fumigation with methyl bro-} mide commonly is used in open-field perennial crop nurseries in California for control of plant-parasitic nematodes, pathogens and weeds. Because this fumigant is being phased out, alternatives are needed to ensure the productivity of the perennial crop nursery industry as well as the ornamental, orchard and vineyard production systems that depend on clean planting stock. As part of the USDA Area-Wide Pest Management Program for Integrated Methyl Bromide Alternatives, several perennial crop nursery projects were conducted in California from 2007 to 2011 to test and demonstrate registered alternative fumigants and application techniques that maximize performance and minimize environmental impacts. The project was designed to evaluate shank application and soil surface sealing methods intended to reduce aboveground emission and improve soil performance of 1,3-dichloropropene, a leading methyl bromide alternative for nurseries. In these garden rose and tree nursery experiments, 1,3-dichloropropene treatments performed well regardless of application techniques. In this article, we highlight recent research and discuss the significance and remaining challenges for adoption of methyl bromide alternatives in this unique nursery stock production system.

$\mathrm{P}$ est- and pathogen-free planting stock is essential for successful establishment and future productivity of new

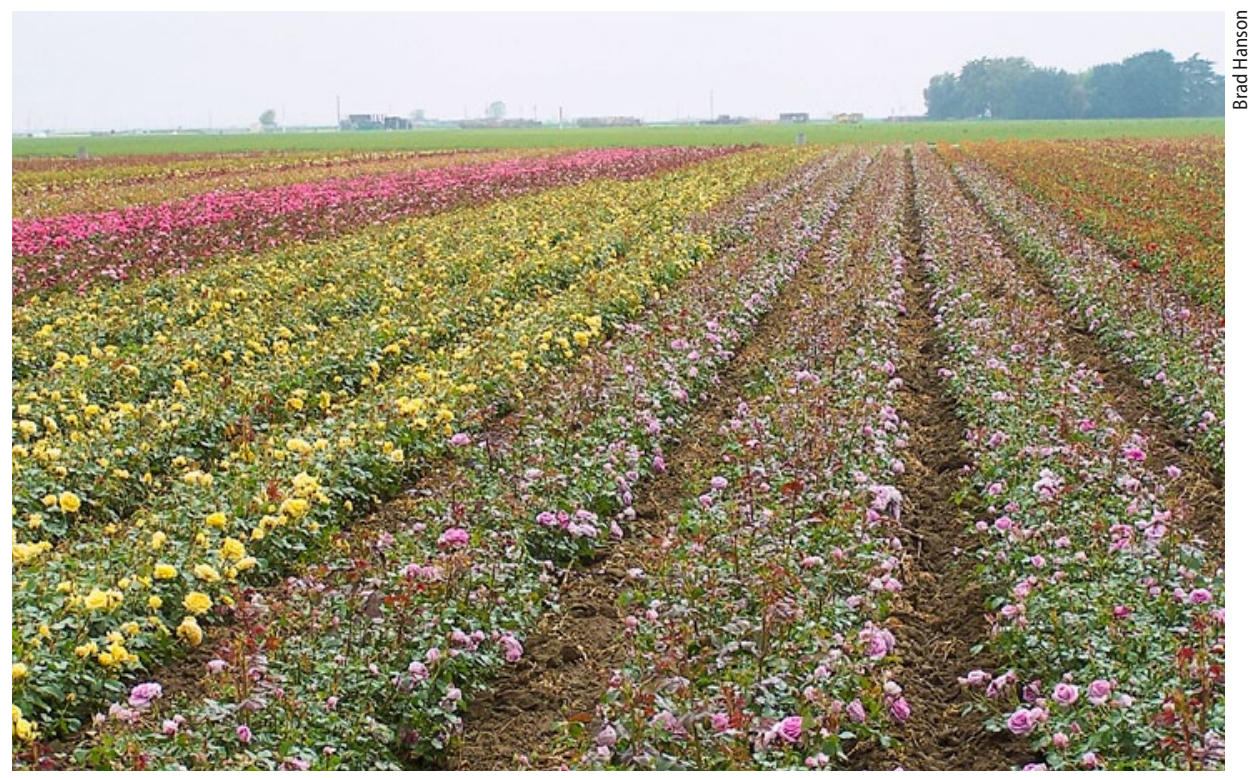

As methyl bromide is phased out, in-ground nursery stock systems face unique challenges. Soil fumigation with 1,3-D can control key nematode pests in nurseries with coarse-textured soils, but long-term sustainability of this option may be limited by other pests and changing regulations.

orchards and vineyards. Clean stock is also a requirement for intrastate, interstate and international commerce of tree, vine and garden rose planting stock. To ensure the quality of commercially produced nursery stock in the state, the California Department of Food and Agriculture (CDFA) enforces laws and regulations related to the production of certified nursery stock as outlined in the Nursery Inspection Procedures Manual (CDFA 2011). Because of the potentially large and long-term impacts on the nursery crop as well as the subsequently planted orchards, vineyards and ornamental landscapes, control of plant-parasitic nematodes in nursery fields is a major focus of the nursery stock certification program.

Producers of perennial crop nursery stock in California can meet nematode certification requirements by fumigating the field at the beginning of the nursery cycle using an approved treatment or by conducting a detailed inspection of soil and planting stock at the end of the production cycle. If growers elect to use inspection procedures instead of approved treatments and soil or plant samples are found to contain prohibited nematodes, further sampling is conducted to delineate the extent of the problem, and nursery stock from the affected area usually is destroyed.

Preplant soil fumigation thus reduces the economic risk of a nonsalable nursery crop and is used in most tree and garden rose nurseries in California. Grapevine nursery stock also must meet phytosanitary requirements to be certified in California, but in contrast to tree and rose growers, many grape nursery producers elect to use the inspection procedures rather than fumigation. In practice, the risk of nematode occurrence in production of grapevine nursery stock without fumigants is reduced by spring planting, a relatively shorter nursery production cycle and market preference for smaller nursery stock. However, grape nursery operations with sandy soils or sites where grapes have been grown previously often use preplant fumigation practices comparable to tree and rose nurseries to reduce the economic and market risks of not meeting phytosanitary regulations.

Most field-grown perennial nursery operations have used methyl bromide (alone or in combination with

Online: http://californiaagriculture.ucanr.edu/ landingpage.cfm?article=ca.E.v067n03p181\&fulltext=yes doi: 10.3733/ca.E.v067n03p181 
chloropicrin) for preplant pest control because it effectively diffuses through the soil profile, penetrates roots and dependably provides effective pest control across a range of soil type and moisture conditions. Under the provisions of the U.S. Clean Air Act and the Montreal Protocol, the import and manufacture of methyl bromide is being phased out because of its deleterious effects on stratospheric ozone. Perennial nursery producers have largely continued using methyl bromide under the critical use exemptions (CUE) and quarantine/preshipment (QPS) criteria (US EPA 2010). However, increasing production costs and international political pressure on CUE and QPS regulations have spurred efforts to identify economically viable alternatives to methyl bromide for the perennial nursery industry.

Several factors limit the adoption of alternative fumigants in California nursery systems. First, there are very few fumigant or nonfumigant nematicides available (Zasada, Halbrendt et al. 2010). In the United States only a handful of fumigants are registered, including methyl bromide, 1,3-dichloropropene (1,3-D), chloropicrin, dimethyl disulfide (DMDS), and methyl isothiocyanate (MITC) generating compounds. Of these, DMDS is not currently registered in California and has had only limited testing in nurseries. Methyl iodide (iodomethane) was registered in California in late 2010, but the federal registration was withdrawn by the manufacturer in early 2012.

The nursery certification program and other regulations further limit available alternatives. Of the fumigants registered in the state, only 1,3-D (alone or in combination with chloropicrin or an MITC generator) is an approved treatment in nurseries with medium- to coarsetextured soils (table 1). However, it is not approved for nurseries with fine-textured (e.g., clay loam) soils because the registered rates are not sufficient to provide acceptable pest control.

Most of the alternative fumigants are heavily regulated due to concerns about human safety (workers, bystanders, neighboring populations) and environmental quality related to emission of fumigants and associated volatile organic compounds (VOCs). These concerns have led to a constantly changing regulatory environment, encompassing buffer zones, field preparation requirements, available compounds and rate limitations on a field and air basin level (US EPA 2012). Uncertainty within the nursery industry about current and pending fumigant regulations presents a continuing challenge to the adoption of methyl bromide alternatives in California.

Although fumigation in the perennial crop nursery industry is driven by nematode certification, there are serious concerns that the level of secondary pest control provided by methyl bromide will not be matched by the alternatives. Weed control with many of the available alternatives is generally not as reliable as with methyl bromide (Hanson and Shrestha 2006). Although weeds can be addressed to a large extent with tillage, hand-weeding, and herbicides, there are likely to be environmental and economic impacts of greater reliance on these techniques. More importantly, many nursery producers are very concerned about the consequences of soilborne diseases that are currently controlled with methyl bromide or methyl bromide and chloropicrin combinations. Reliance on alternatives with narrower pest control spectrums may result in problems with new diseases or the resurrection of old ones.

Research has been conducted in recent years to address issues limiting adoption of methyl bromide alternatives in California's perennial crop nursery industry (Hanson and Schneider 2008; Hanson et al. 2010; Jhala et al. 2011; Schneider and Hanson 2009; Schneider et al. 2009). As part of the USDA-ARS Pacific Area-wide Pest Management Program for Integrated Methyl Bromide Alternatives, two additional research and demonstration projects were implemented from 2007 to 2010. First, because current and pending regulations greatly affect how and when fumigants can be used, a research station field trial was conducted to simultaneously determine the effects of emission reduction techniques on pest control and fumigant emissions. Second, two trials were conducted in commercial nurseries
TABLE 1. Summary of currently approved treatment schedules for producing certified nematode-free nursery stock in California*

\begin{tabular}{|c|c|c|c|}
\hline Material & Application method & Sandy soil & Clay loam soil \\
\hline & & & 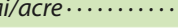 \\
\hline \multicolumn{4}{|c|}{$\begin{array}{l}\text { Schedule A: Sites known to be infested with plant-parasitic nematodes, or not previously treated and } \\
\text { unknown nematode pest status }\end{array}$} \\
\hline Methyl bromide & Tarped $\dagger$ & 300 & 400 \\
\hline Methyl bromide & Dual application $\neq$ & $300+150$ & $400+150$ \\
\hline \multicolumn{4}{|c|}{$\begin{array}{l}\text { Schedule B: Protection for 26-month June-budded crop if soil has been previously treated or tested for } \\
\text { nematodes. }\end{array}$} \\
\hline Methyl bromide & Tarped & 300 & 400 \\
\hline Methyl bromide & Dual application & $300+150$ & $400+150$ \\
\hline $1,3-D$ & Dual application & $313+142$ & Not approved \\
\hline
\end{tabular}

Schedule C, Chart I: Shallow-rooted nursery plants in place for only one season (strawberry, June-budded fruit trees, or vegetable plants).

\begin{tabular}{llll} 
Methyl bromide & Tarped & 200 & 300 \\
\hline Methyl bromide & Dual application & $300+150$ & $400+150$ \\
\hline $1,3-D$ & Dual application & $285+142$ & Not approved
\end{tabular}

Schedule C, Chart II: Protection for a 26-month crop

1,3-D Tarped $\quad 332 \quad$ Not approved

Schedule D: Lists a series of 1,3-D plus additional fumigants or nematicides with rates adjusted for soil moisture. Several of these treatments are approved by CDFA but not currently allowed due to California registration or label restrictions.

Schedule E: Lists a series of methyl iodide treatments approved by CDFA; however, the fumigant is not currently registered in California.

\footnotetext{
* More detail available from the Nursery Inspection Procedures Manual, Item 7 (CDFA 2011).

† Field is covered with a broadcast application of high-density polyethylene (HDPE) film.

₹ Field is treated once, then the soil is inverted with a plow, and the field is treated with the second application in an effort to fully treat the surface soil layers.
} 
to test and demonstrate pest control and nursery stock productivity with 1,3-D treatments in an effort to increase grower experience and comfort with available alternatives.

\section{Emission flux and efficacy trial}

A shank fumigation trial was conducted in 2007 at the UC Kearney

Agricultural Center (KAC), near Parlier, to determine the effect of two fumigation shank types and five soil surface treatments on 1,3-D emissions and control of representative soilborne pests following removal of a plum orchard. Soil texture at the site was a Hanford fine, sandy loam with $\mathrm{pH} 7.2,0.7 \%$ organic matter, and a composition of $70 \%$ sand, $24 \%$ silt and $6 \%$ clay. The experiment included 10 treatments with 1,3-D in a split plot design with surface treatments as the main plots and two application shank types as the subplots, as well as an unfumigated control and a methyl bromide plus chloropicrin standard for comparison (table 2). Individual plots were 12 feet by 100 feet, and each treatment was replicated three times.

Fumigant application. Fumigants were applied using commercial equipment (TriCal, Hollister, CA) on Oct. 2, 2007. Methyl bromide with chloropicrin (98:2) was applied at 350 pounds per acre with a Noble plow rig set up to inject fumigants 10 inches deep through emitters spaced 12 inches apart while simultaneously

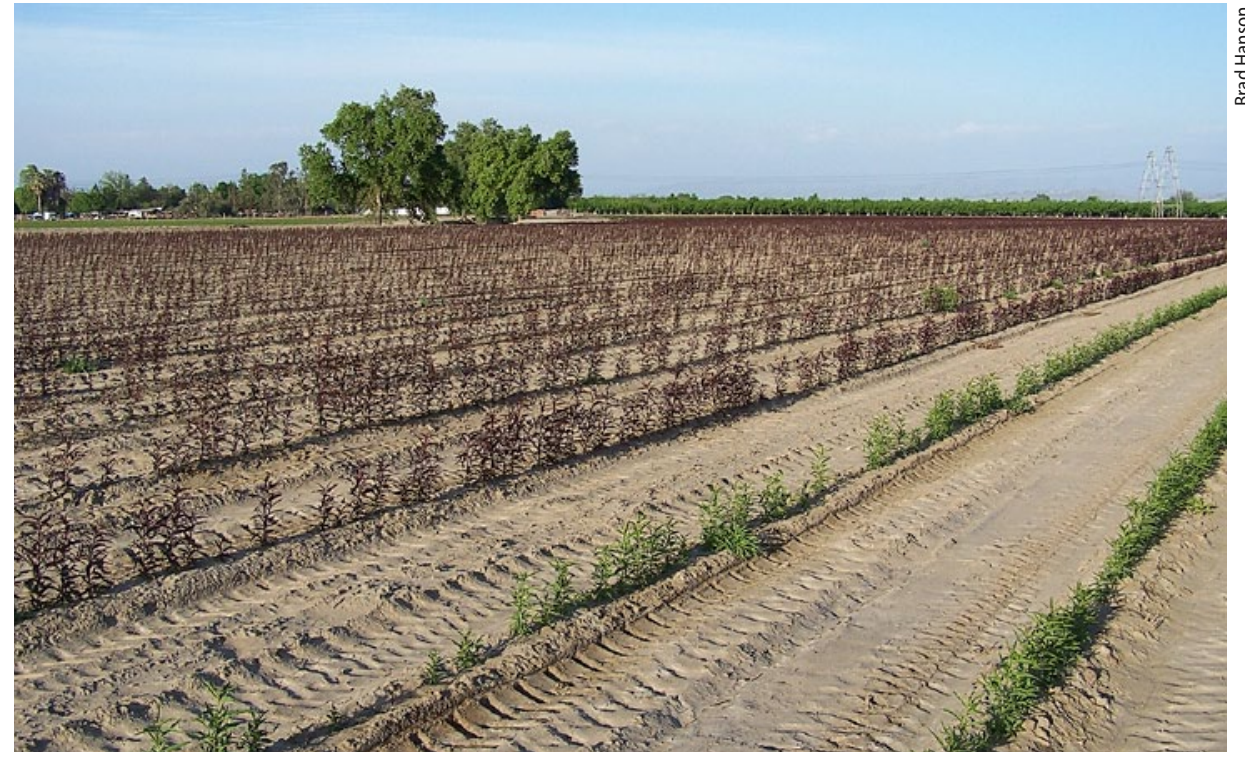

In-ground production of perennial nursery stock often begins with a seeded or vegetatively produced rootstock planted in the fall followed by budding or grafting of a preferred scion the following spring. Most nursery fields are fumigated prior to planting the nursery crop in order to meet certification requirements. installing 1-mil high-density polyethylene (HDPE) film. The 1,3-D (Telone II, Dow AgroSciences, Indianapolis, IN) treatments, at 332 pounds per acre, were applied using either a standard Telone rig with shanks spaced 20 inches apart and an injection depth of 18 inches or a Buessing shank rig with shanks spaced 24 inches apart and the fumigant injection split at 16- and 26-inch injection depths. The Buessing shank also had wings above each injection nozzle to scrape soil into the shank trace and minimize
TABLE 2. Treatments in an emission flux study in 2007, a rose nursery in 2007 and a tree nursery in 2008 to evaluate effects of surface treatments and application rigs on nematode, pathogen and weed control with 1,3-D

\begin{tabular}{|c|c|c|c|}
\hline Treatment & Rate & Surface treatment* & Shank system \\
\hline & pounds ai/acre & & \\
\hline Untreated & -- & -- & -- \\
\hline Methyl bromidet & 350 & HDPE film & Noble plow \\
\hline $1,3-\mathrm{D}$ & 332 & HDPE film & Standard Telone rig \\
\hline $1,3-D$ & 332 & HDPE film & Buessing shank rig \\
\hline 1,3-D followed by metam sodium & $332+160$ & Bare soil & Standard Telone rig \\
\hline 1,3-D followed by metam sodium & $332+160$ & Bare soil & Buessing shank rig \\
\hline $1,3-D$ & 332 & Intermittent water seals & Standard Telone rig \\
\hline $1,3-D$ & 332 & Intermittent water seals & Buessing shank rig \\
\hline $1,3-D$ & 332 & VIF & Standard Telone rig \\
\hline $1,3-\mathrm{D}$ & 332 & VIF & Buessing shank rig \\
\hline 1,3-D dual application $\neq$ & $332+150$ & Bare soil & Standard Telone rig \\
\hline 1,3-D dual application & $332+150$ & Bare soil & Buessing shank rig \\
\hline
\end{tabular}

* HDPE, VIF and intermittent water seals were surface seal treatments, while 1,3-D dual application and 1,3-D followed by metam sodium were surface soil treatments.

† The methyl bromide formulation used in these experiments was $98 \%$ methyl bromide plus $2 \%$ chloropicrin as a warning agent.

₹ 1,3-D dual application treatments were included only in the 2007 rose nursery trial. rapid upward movement of the fumigant (McKenry et al. 2003).

Following 1,3-D application, a disk and ring roller was used to level and compact the surface soil before surface seals were applied over the fumigated plots. Average soil temperature at 20 inches during fumigation was $70^{\circ} \mathrm{F}$, and soil moisture was $8.2 \%$ to $10.5 \%$ weight per weight $(\mathrm{w} / \mathrm{w})$ in the top 3 feet.

Surface treatments included HDPE film; virtually impermeable film, VIF (Bromostop, Industria Plastica Monregalese, Italy); and a series of intermittent water applications (water seals). HDPE and VIF film was installed after the disk and rolling operation using a Noble plow rig. The intermittent water seals treatment was applied using a temporary sprinkler system installed in the plots following fumigation and the postfumigation tillage operation; water was applied four times in the first 2 days after fumigation: 0.5 inch after 3 hours, 0.2 inch after 12 hours, 0.2 inch after 24 hours and 0.2 inch after 48 hours.

All plastic films were removed 10 days after fumigation. Fourteen days after the initial 1,3-D fumigation, the metam sodium treatment was applied through sprinklers at 160 pounds per acre in 2.75 inches of water. For the dual application treatment, 21 days after the initial treatment, soil was inverted with a moldboard plow and an additional 1,3-D treatment (150 pounds per acre) was applied with 
the previously described Telone rig and rolling operation.

Emissions data collection. Fumigant emissions from eight 1,3-D treatments two application shank types times four surface seal methods (bare soil, water seals, HDPE, VIF) - were monitored in three replicate plots for 10 days following the initial application. Emission of 1,3-D from the soil surface was monitored using previously described dynamic flux chamber techniques (Gao and Wang 2011; Gao et al. 2011). Briefly, a flow-through flux chamber with a 10-inch-by-20-inch opening was installed on the surface (of the soil or plastic film) following fumigant injection and installation of the films or after the initial water seal treatment (chambers were relocated after each subsequent water seal).

These chambers allow semi-automated, continuous sampling of fumigant concentrations in the air above the surfaces. The cis- and trans-isomers of 1,3-D were trapped in charcoal sampling tubes (Orbo-32 standard charcoal tubes, Supelco, Bellefonte, PA). The two 1,3-D isomers were summed as total 1,3-D for data analysis and reporting. Individual tubes were removed from the flux chambers every 3 to 6 hours and stored frozen until laboratory processing. Emission flux and cumulative emission during the 10-day monitoring period were calculated based on surface area and air flow rates through the flux chambers, and treatment differences were compared using analysis of variance (SAS v.9.1, SAS Institute, Cary, NC).

The concentration of 1,3-D in the soil-gas phase was determined 6, 12, 24, 48,120 and 240 hours after treatment. At each time point, samples were collected using a multiport sampling probe and a system of gas-tight syringes to draw air from eight depths $(0,2,4,8,12,18,24$ and 36 inches) through charcoal sampling tubes. Samples were stored frozen until analysis.

In the laboratory, all samples were processed using procedures described by Gao et al. (2011). Briefly, sample tubes were broken and trapped fumigants were extracted from the trapping matrix with ethyl acetate and analyzed using a gas chromatograph (Agilent Technology, Palo Alto, CA) equipped with a micro electron capture detector ( $\mu \mathrm{ECD})$.

Pest control data collection. Pest control efficacy was evaluated using citrus nematode bioassay counts, fungal dilution plating, and weed emergence counts and biomass collections from each replicated plot. The pest control data from this research station emission flux experiment were reported in Jhala et al. (2011).

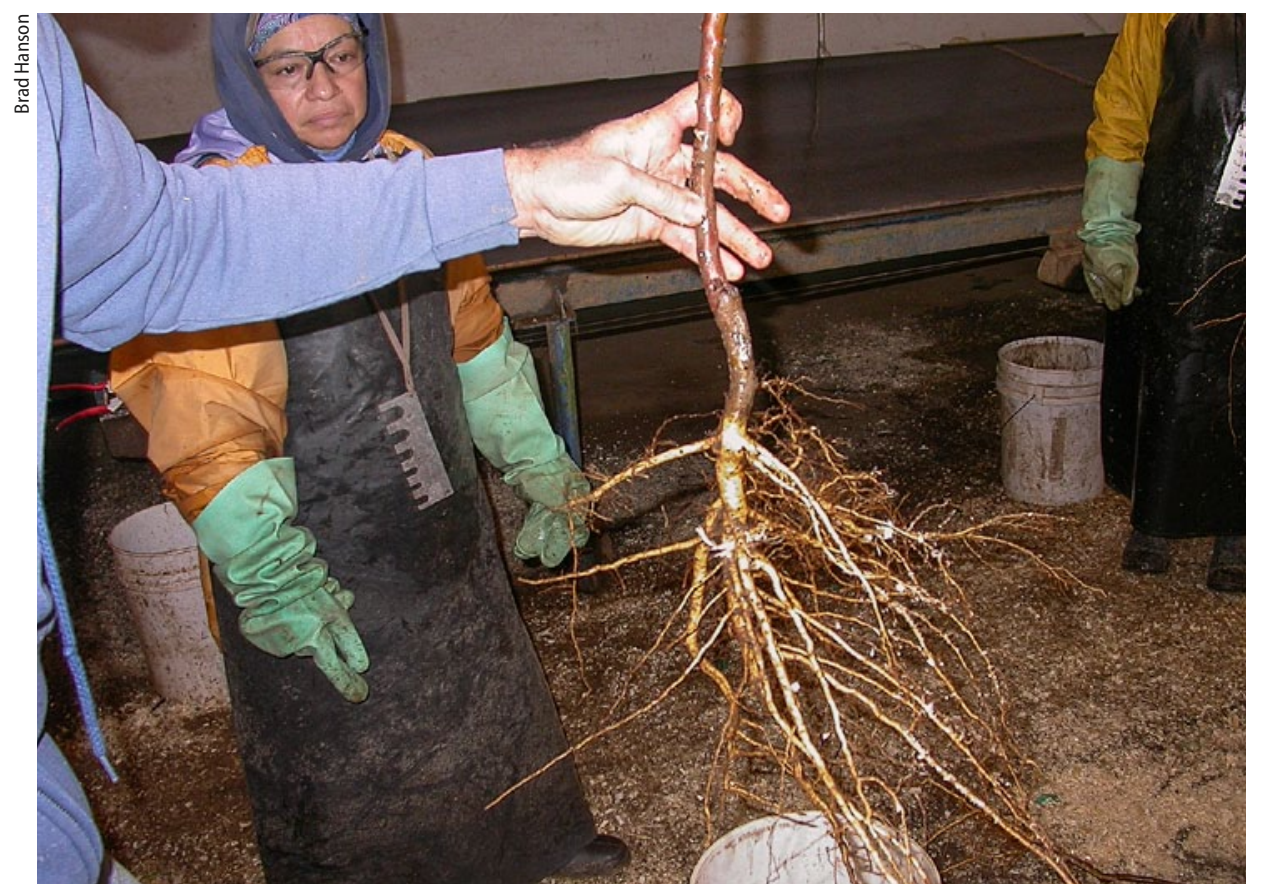

Depending on the crop, dormant bare-root plants are harvested 14 to 26 months after budding or grafting. If the field was not fumigated before planting, plants and soil are inspected at harvest. If nematodes are present, the crop usually is destroyed.

\section{Rose and tree nursery trials}

In addition to the emission flux and efficacy study conducted at KAC, two field trials were conducted in commercial nurseries to evaluate pest control efficacy and nursery stock productivity. Fumigation and surface treatments in the nursery experiments were the same as in the flux study with minor exceptions (table 2). The commercial nursery trials were arranged as randomized complete block experiments with a split plot arrangement of 1,3-D treatments. The whole plot factor was surface treatment, and the split plot factor was the shank type. Individual plots in these experiments were 22 feet by 90 feet, and each treatment was replicated four times.

Fumigant application. In 2007, the experiment was established in a garden rose nursery near Wasco. The soil at the rose nursery site was a McFarland loam with $\mathrm{pH} 6.2,0.9 \%$ organic matter and $74 \%$ sand, $13 \%$ silt and $13 \%$ clay. Treatments were applied on Nov. 7, 2007, when the soil temperature was $64^{\circ} \mathrm{F}$ and soil moisture averaged $9.2 \% \mathrm{w} / \mathrm{w}$ from 2 to 5 feet. The experiment was repeated in 2008 in a deciduous tree nursery near Hickman, in a Whitney and Rocklin sandy loam soil with pH $6.5,0.8 \%$ organic matter, and $66 \%$ sand, $23 \%$ silt and $11 \%$ clay. Treatments in the tree nursery trial were applied on Aug. 13, 2008, when the soil was $80^{\circ} \mathrm{F}$ and soil moisture ranged from $5.0 \%$ to $12.6 \%$ $\mathrm{w} / \mathrm{w}$ in the top 5 feet.

Immediately following 1,3-D application, a disk and roller were used to compact the soil and disrupt shank traces and HDPE and VIF were installed using the Noble plow rig. For the water seal main plots, a temporary sprinkler system was installed after the postfumigation tillage operation and intermittent water seals were applied: 0.5 inch after 3 hours, and 0.2 inch each after 12, 24 and 48 hours.

The dual application 1,3-D treatments were applied in the garden rose experiment on Nov. 28, 2007, but were not included in the 2008 tree nursery experiment. Metam sodium (150 pounds per acre) was applied in 2.75 inches of irrigation water through sprinklers 14 to 30 days after the initial 1,3-D treatment in both experiments. All plastic films were removed 2 to 3 weeks after fumigation at both sites.

Crop production and data collection. Both nursery trials were managed by the 
cooperating growers using their standard practices for planting, fertilization, in-season tillage and budding and harvest operations. In the 2007 rose experiment, two rows each of the rose rootstock 'Dr. Huey' and the own-rooted garden rose variety 'Home Run' were planted as hardwood cuttings in December 2007. Rose nursery stock was planted 7 inches apart in furrows spaced 3 feet apart, and the field was furrow irrigated during the 2008 and 2009 growing seasons. The own-rooted cultivar was harvested after one growing season in January 2009, and the unbudded 'Dr. Huey' rootstock was harvested in February 2010 after an additional growing season. At both harvest dates, all plants in one 90-foot row were lifted using a singlerow undercutting digger, plants were bundled and tagged by plot, and graded in a commercial packinghouse.

In the 2008 tree nursery trial, two rows each of the peach rootstock 'Nemaguard' (from seed) and the plum rootstock 'Myro $29 C^{\prime}$ (hardwood cuttings) were planted with 8 inches between plants and 5 feet between rows in December 2008. The tree nursery plots were sprinkler irrigated during the 2009 growing season. Due to the market needs of the cooperating nursery, the rootstocks in the tree trial were not available for harvest and grading as a part of the experiment.

Pest control efficacy and crop productivity were evaluated during the 12- or 26-month nursery production cycle. Nematode control was determined using a citrus nematode bioassay in which two sets of muslin bags containing 100 grams of soil infested with citrus nematode (Tylenchulus semipenetrans Cobb) were buried at 6, 12, 24 and 36 inches below the soil surface in each plot prior to fumigation.

The initial population of citrus nematodes in infested soil was 4,086 and 3,876 nematodes per 100 cubic centimeters of soil in 2007 and 2008, respectively. The bags were recovered 1 month after fumigation, nematodes were extracted from 100 cubic centimeters of soil using the Baermann funnel protocol, and surviving nematodes were identified and counted.

To evaluate the effect of fumigation treatments on soil fungal populations, ten 1-inch-by-12-inch soil cores were collected from each subplot 2 weeks after fumigation. Soils were homogenized, and a subsample was assayed for Fusarium oxysporum Schlecht. and Pythium species using

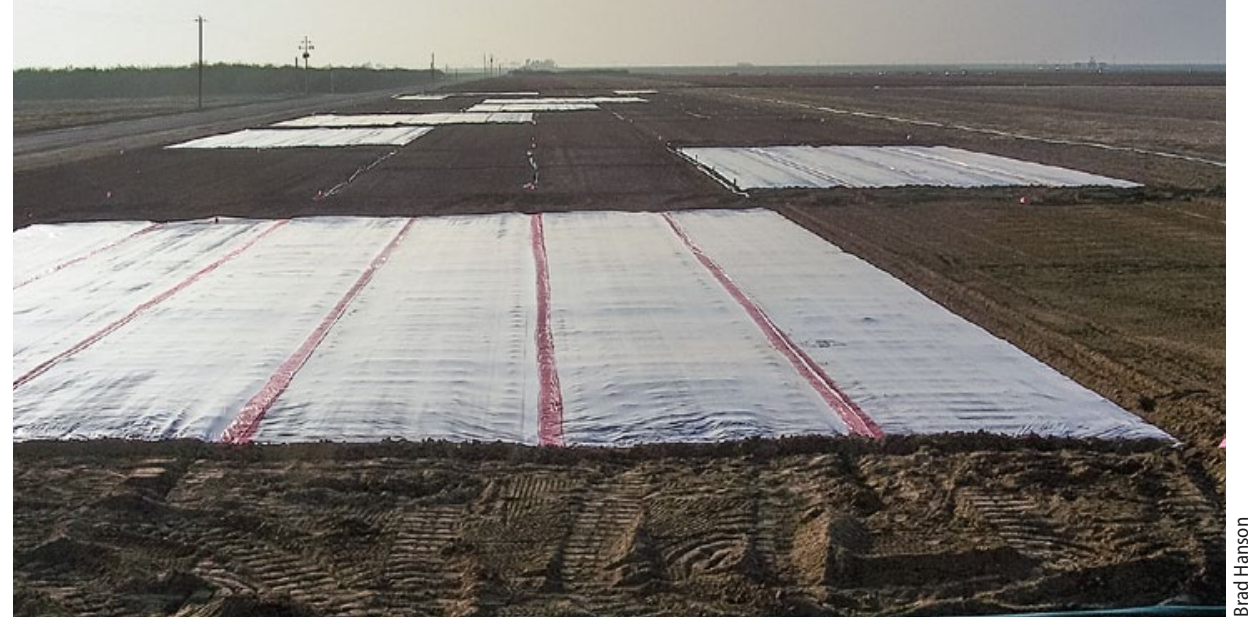

At a 2-acre commercial rose nursery trial near Wasco, 1,3-D was treated with a combination of application shank types and surface treatments. A similar trial was also conducted at a commercial tree nursery near Visalia.

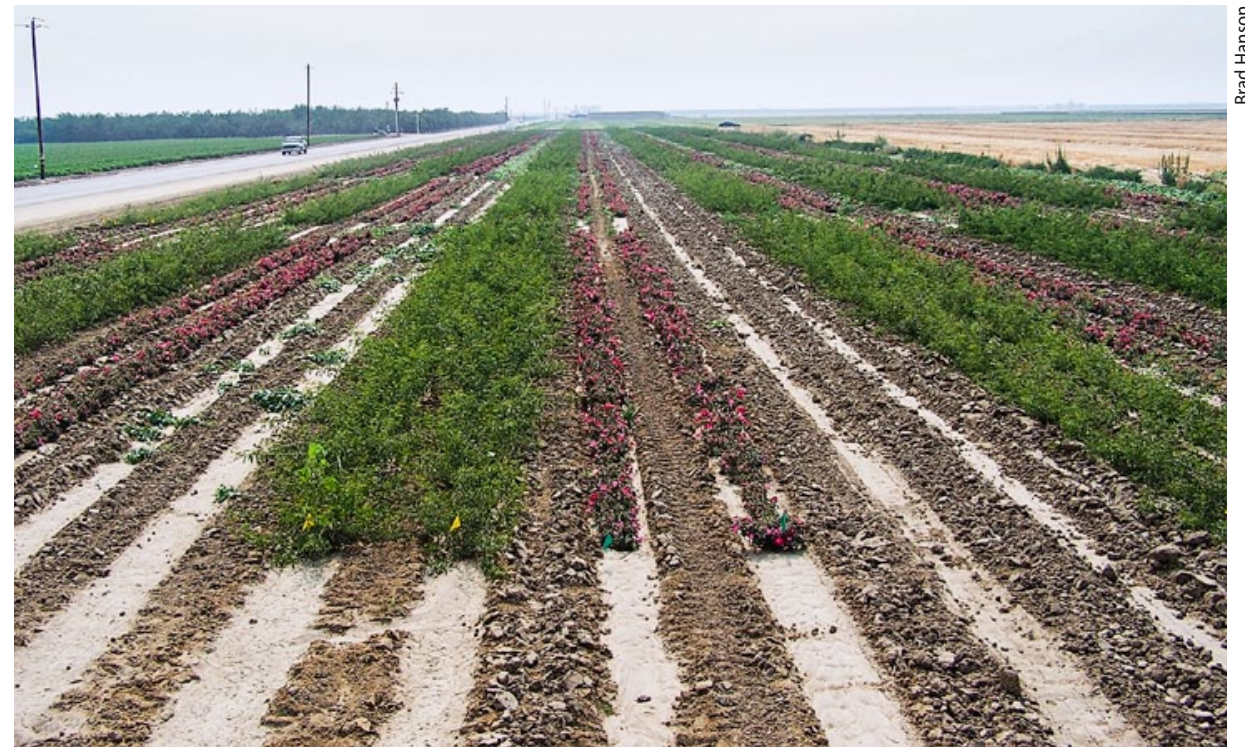

'Home Run' and 'Dr. Huey' garden rose cultivars growing in treated plots six months after fumigation with 1,3-D or methyl bromide.

dilution plating techniques on selective media. Pythium species samples were plated on $\mathrm{P}_{5} \mathrm{ARP}$ medium for 48 hours, and F. oxysporum samples were plated on Komada's medium for 6 days.

Emerged weeds in a 1-square-meter area were identified and counted twice in the winter following the fall fumigation and several times during the subsequent summer growing season.

Nursery stock establishment, vigor and growth were monitored during the season. Visual evaluations of crop vigor were made on a scale of 1 to 7 , where 7 was the most vigorous and 1 was dead or dying plants. Near the end of the growing season, trunk diameter of 10 plants in each subplot was measured 3 inches above the soil surface using a dial caliper. As previously described, rose nursery stock was harvested and graded to commercial standards ratings, but tree nursery stock was not harvested as a part of the experiment.

Data were subjected to analysis of variance, and initial analyses indicated that the shank types (i.e., standard vs. Buessing shanks) did not differ in their effect on any of the pest control or crop growth parameters measured. Thus, data from the two shank type treatments were grouped together within surface treatments and reanalyzed with seven treatments (2007) and six treatments (2008). The nematode, pathogen and weed density data were transformed $[\ln (x+1)]$ to stabilize the variance prior to analysis; however, means of untransformed data are presented for clarity. Treatment means were separated using Fisher's protected 
least significant difference (LSD) procedure with $\alpha=0.05$.

\section{KAC emission flux results}

Emission flux. Within a surface treatment, there were no statistical differences in emission flux between the two application shank types, thus data were combined over application rig. However, significant differences in 1,3-D emission flux were observed among surface treatments (fig. 1). Fumigant emission flux from bare plots was two times higher than from water seals and HDPE and nearly 15 times higher than from VIF within 48 hours after treatment. Emission from water-sealed plots was reduced during the sequential water applications, but flux was similar to bare soil plots after 48 hours. HDPE film continued to give lower emission rates than the bare soil and water seals but was significantly higher than VIF. Throughout the monitoring period, VIF-covered plots had the lowest 1,3-D emissions; maximum flux was 11 micrograms per square meter per second $\left(\mu \mathrm{g} \mathrm{m}^{-2} \mathrm{~s}^{-1}\right)$, which was at least $90 \%$ lower than that from the bare soil plots. Relative to the bare soil treatment, estimated cumulative 1,3-D emission losses for water seals, HDPE and VIF were $73 \%, 45 \%$ and $6 \%$, respectively, which were similar to reports from a previous field study (Gao et al. 2011).

Headspace 1,3-D concentration. Concentration of 1,3-D immediately below the plastic film (headspace) indicated that 1,3-D retention is much greater under VIF film than under HDPE (fig. 2). Several other studies have shown that VIF can retain substantially higher fumigant

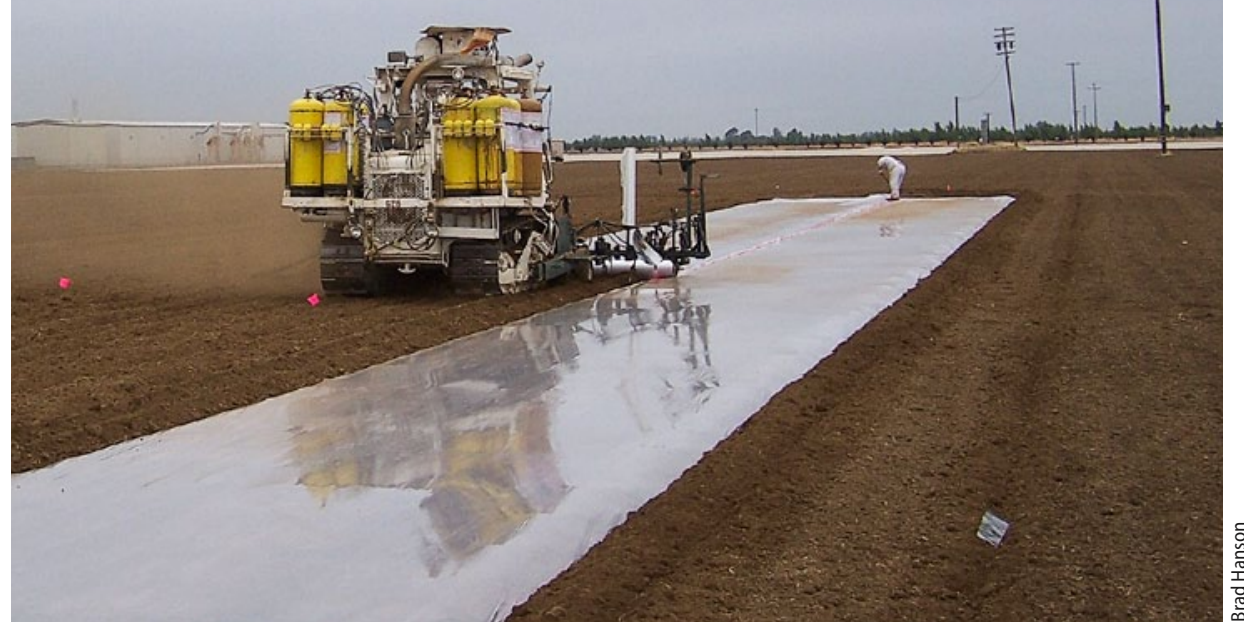

Large-plot soil fumigation experiments in commercial nurseries test and demonstrate available methyl bromide alternatives under real-world conditions. Above, HDPE application at a tree nursery trial near Yuba City, CA. concentrations without negatively affecting nematode, pathogen and weed control efficacy or crop yield (Fennimore and Ajwa 2011; Hanson et al. 2010).

Fumigant distribution in soil. Initial analysis of fumigant distribution in the surface 90 centimeters ( 3 feet) indicated that there were no differences between the application shanks within a surface treatment in this zone; thus data were combined over application shank types (fig. 3). The 1,3-D concentration was highest near the injection depth, at 45 centimeters (18 inches) and lowest near the soil surface, at 5 centimeters ( 2 inches), and at 90 centimeters ( 3 feet), but this difference diminished over time.

The effect of depth on 1,3,-D concentration was most evident in water seals and bare soil plots. HDPE and VIF plots had more uniform distribution of the fumigant through the soil profile (5 to 90 centimeters, 2 to 36 inches) than the water seals plots, especially 48 hours after
TABLE 3. Effects of surface treatments with 1,3-D on Fusarim and Pythium spp. propagules in a commercial rose nursery in 2007 and tree nursery in 2008

\begin{tabular}{|c|c|c|c|c|c|c|c|c|}
\hline \multirow[b]{2}{*}{ Treatment } & \multicolumn{4}{|c|}{ Rose nursery } & \multicolumn{4}{|c|}{ Tree nursery } \\
\hline & \multicolumn{2}{|c|}{ Fusarium } & \multicolumn{2}{|c|}{ Pythium } & \multicolumn{2}{|c|}{ Fusarium } & \multicolumn{2}{|c|}{ Pythium } \\
\hline & n....... & $\ldots$ & - colo & rmir & its/gram & $i i^{*}$. & $\ldots \ldots$ & \\
\hline Untreated & 5.4 & a & 14.8 & a & 101.5 & a & 99.5 & a \\
\hline Methyl bromide & 0.0 & $b$ & 0.0 & $b$ & 0.0 & c & 0.0 & c \\
\hline 1,3-D dual application & 0.0 & b & 1.9 & $\mathrm{~b}$ & $-\dagger$ & & - & \\
\hline 1,3-D (HDPE film) & 0.4 & $b$ & 0.9 & $\mathrm{~b}$ & 6.2 & $b$ & 0.2 & c \\
\hline 1,3-D (VIF) & 0.8 & b & 0.6 & b & 2.1 & bc & 0.0 & c \\
\hline 1,3-D followed by metam sodium & 1.0 & b & 6.8 & a & 137.4 & a & 3.1 & b \\
\hline 1,3-D (water seals) & 0.0 & $b$ & 7.5 & a & 65.7 & $\mathrm{a}$ & 11.4 & $\mathrm{~b}$ \\
\hline
\end{tabular}

* Representative soil samples were collected in the surface 12 inches of each plot. The data were log transformed $[\ln (x+1)]$ for homogenous variance prior to analysis; however, data presented here are the means of actual values for comparison. Least square means within columns with no common letters are significantly different according to Fisher's protected LSD test where $P<0.05$.

† The 1,3-D dual application treatment was not included in the 2008 tree nursery trial. treatment. However, 1,3-D concentration under the VIF tarp was markedly higher than in all other treatments, which suggests that there could also be differences in the top 5 centimeters ( 2 inches) of soil. These results imply that the use of a highly impermeable tarp can lead to a more uniform distribution of fumigants in the soil profile and may allow satisfactory pest control with reduced application rates (Fennimore and Ajwa 2011; Gao et al. 2011; Hanson et al. 2010).

Soilborne pest control. Pest control data from the $2007 \mathrm{KAC}$ emissions trial and a related 2008 emissions trial were reported previously (Jhala et al. 2011) and are not shown here. In general, however, there were few differences in pest control attributed to the fumigant application shanks used in the trial. Pythium species populations were lower in all treatments than in the untreated control, but no statistical differences were noted in Fusarium species populations among treatments. The high 1,3-D rates and well-prepared soils resulted in complete control of citrus nematodes in the bioassay bags in all treatments and depths.

Weed populations were variable among treatments but tended to be lowest in methyl bromide plots and 1,3-D plots sealed with VIF and highest in the water seals and dual 1,3-D application treatments.

\section{Commercial nursery results}

Nematodes and soilborne pathogens. All treatments of 1,3-D or methyl bromide effectively controlled citrus nematodes in bioassay bags buried at 12-, 24- and 36 -inch depths in each plot. However, these results, which were obtained in 


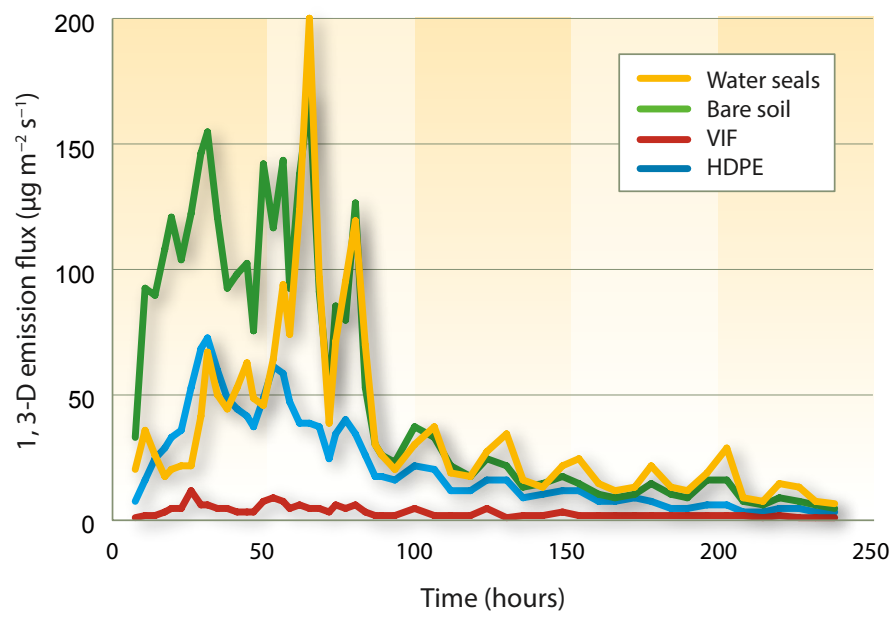

Fig. 1. Emission flux of 1,3-dichloropropene (1,3-D) with different surface treatments in a 2007 Kearney Agricultural Center field trial, near Parlier. Data were collected from three replicate plots and averaged over two application shank types $(n=6)$
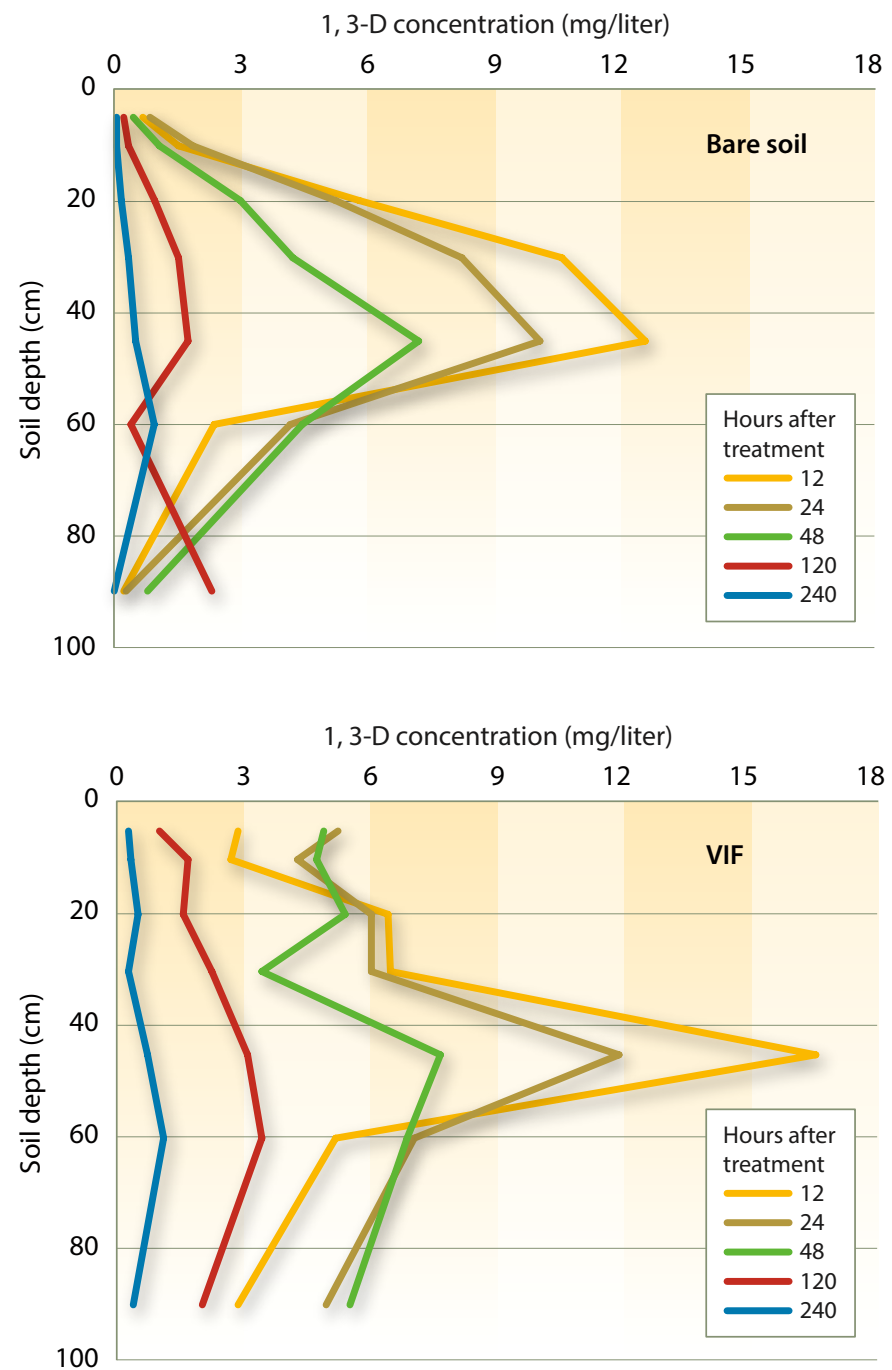

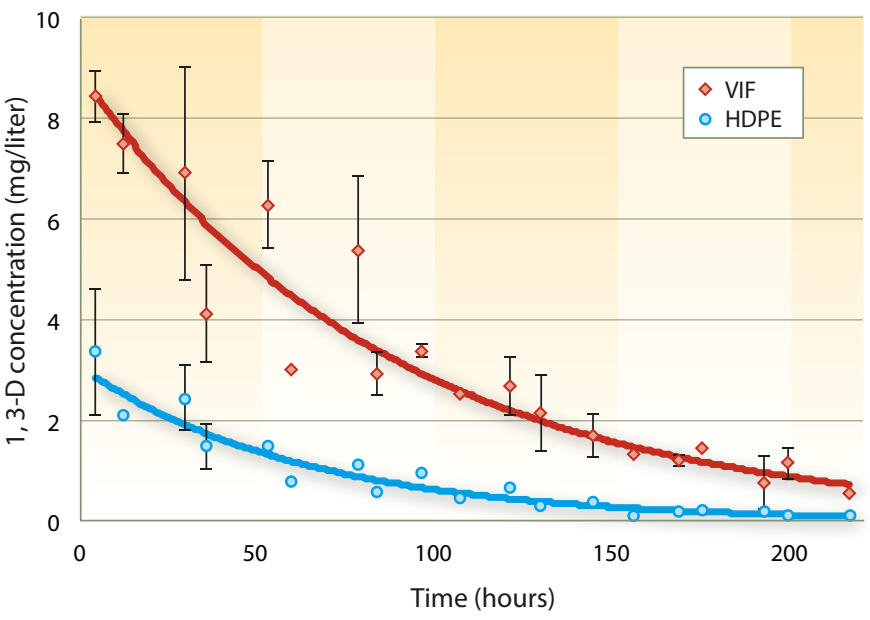

Fig. 2. Air concentration of 1,3-D between the soil surface and plastic film following application of 332 pounds per acre Telone II sealed with VIF or HDPE film $(n=3)$ in a 2007 Kearney Agricultural Center field study, near Parlier.
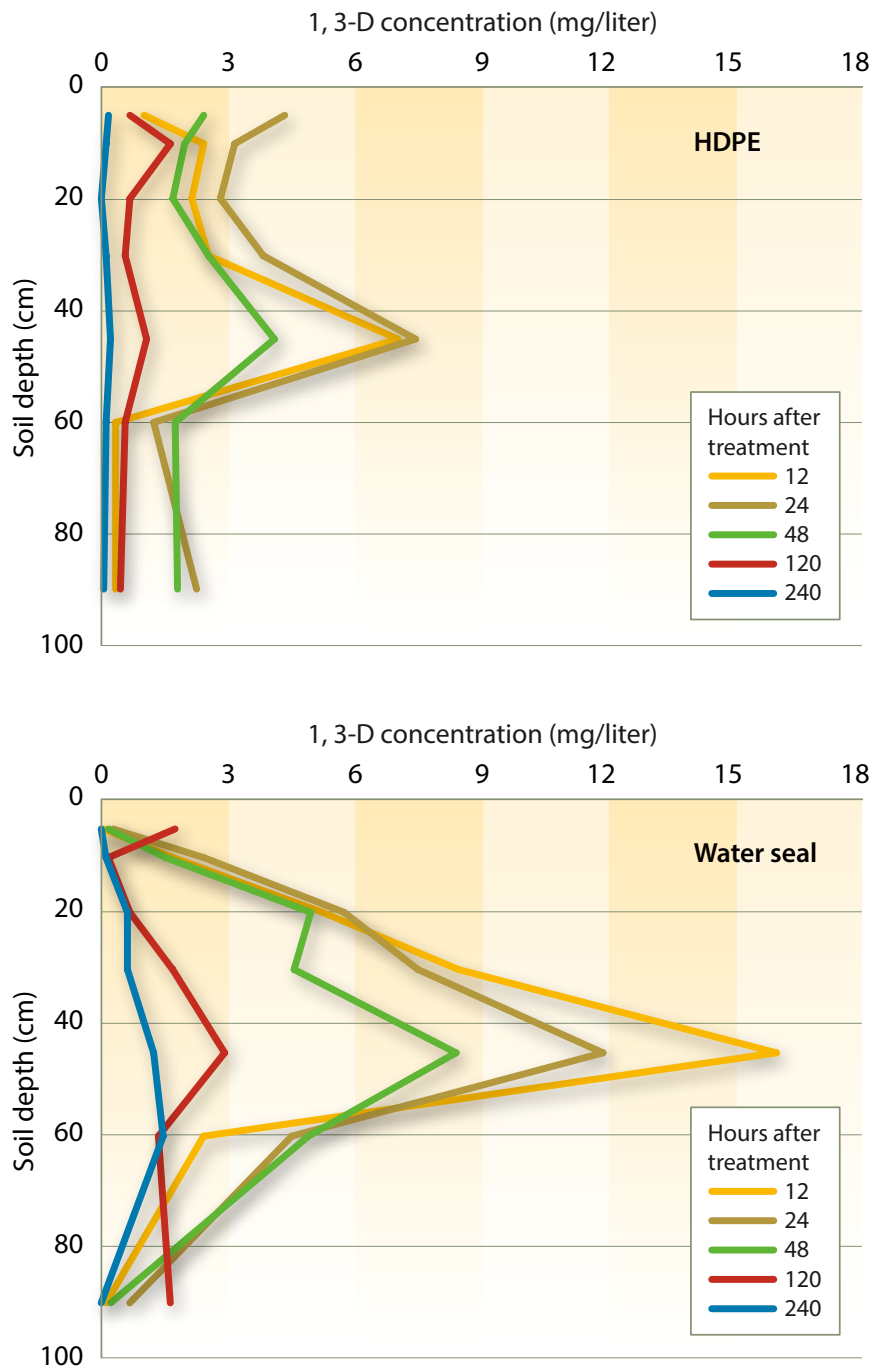

Fig. 3. Distribution of gas 1,3-D in the soil profile after shank injection in a 2007 Kearney Agricultural Center field study, near Parlier. Data were collected $12,24,48,120$ and 240 hours after treatment from three replicate plots and are averaged over two application shank types $(n=6)$. 
well-prepared sandy soils with low pest and pathogen populations, may not apply to more challenging field conditions (Hanson et al. 2010). Applications of 1,3-D sealed with HDPE or VIF and dual application 1,3-D treatments reduced Fusarium and Pythium species propagules in the soil compared with the untreated plots (table 3). These treatments were comparable to methyl bromide in controlling Fusarium and Pythium species.

Soil pathogen control with 1,3-D followed by metam sodium and 1,3-D with intermittent water seals was inconsistent between the two experiments, which suggests that specific micro- and macro-level differences in environmental and field conditions may contribute to greater treatment variability and risk to growers.

Weed density. When 1,3-D was sealed with HDPE and VIF, broadleaf weed density was reduced to less than 6 weeds per square meter, which was comparable to methyl bromide (table 4). These results are similar to a previous nursery study that indicated 1,3-D or 1,3-D plus chloropicrin sealed with HDPE or VIF resulted in weed seed viability and hand-weeding time comparable to methyl bromide (Shrestha et al. 2008). Generally, intermittent water seals after a 1,3-D application resulted in broadleaf weed density similar to the untreated control. Most weeds germinate near the soil surface, thus techniques such as intermittent water seals

TABLE 4. Effects of surface seal treatments with 1,3-D on broadleaf weed density in a commercial rose nursery trial in 2007 and on broadleaf and grass weed density in a tree nursery trial in 2008

\begin{tabular}{|c|c|c|c|c|c|c|c|c|}
\hline \multirow[b]{3}{*}{ Treatment } & \multicolumn{4}{|c|}{ Rose nursery } & & & & \\
\hline & \multirow{2}{*}{\multicolumn{2}{|c|}{$\begin{array}{c}\text { 'Home Run' } \\
\text { Broadleaf }\end{array}$}} & \multirow{2}{*}{\multicolumn{2}{|c|}{$\begin{array}{c}\text { 'Dr. Huey' } \\
\text { Broadleaf }\end{array}$}} & \multicolumn{4}{|c|}{ Tree nursery } \\
\hline & & & & & \multicolumn{2}{|c|}{ Broadleaf } & \multicolumn{2}{|c|}{ Grass } \\
\hline & \multicolumn{8}{|c|}{ 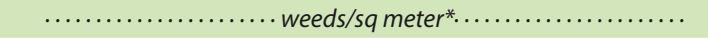 } \\
\hline Untreated & 32.5 & $\mathrm{a}$ & 44.7 & a & 243.7 & a & 24.3 & a \\
\hline Methyl bromide & 0.6 & c & 0.4 & c & 5.4 & $c$ & 0.0 & C \\
\hline 1,3-D dual application & 11.8 & $b$ & 1.9 & c & $-\dagger$ & & - & \\
\hline 1,3-D (HDPE film) & 2.3 & $c$ & 0.6 & c & 6.0 & c & 0.0 & $c$ \\
\hline 1,3-D (VIF) & 1.7 & c & 0.7 & c & 4.1 & $c$ & 0.1 & C \\
\hline 1,3-D followed by metam sodium & 15.2 & $\mathrm{~b}$ & 3.3 & c & 23.3 & $\mathrm{~b}$ & 0.1 & $c$ \\
\hline 1,3-D (water seals) & 29.0 & $a$ & 16.7 & $b$ & 182.1 & $a$ & 9.1 & $b$ \\
\hline
\end{tabular}

that limit upward fumigant movement into surface soils can adversely affect weed control. The other surface treatments 1,3-D dual application and 1,3-D followed by metam sodium) had intermediate broadleaf weed densities compared to untreated plots and methyl bromide.

All fumigation treatments reduced grass weed populations compared to the control plots; however, the greatest reductions were observed in plots treated with methyl bromide, 1,3-D sealed with HDPE or VIF, and 1,3-D followed by metam sodium. It was clear in this study that effective surface treatments can greatly increase weed control with 1,3-D; however, even the best treatments will likely require supplemental weed control to meet grower expectations.

Stock vigor and performance. Effects of surface seal treatments and 1,3-D soil fumigation on nursery stock vigor and performance in two nursery trials were evaluated in 2007 to 2010 (table 5). In the rose nursery trial, all treatments had similar rootstock vigor and number of marketable plants except when 1,3-D was followed by metam sodium. During the 2008 growing season, roses grown in plots treated with 1,3-D followed by metam sodium had lower vigor than the other treatments; however, by harvest at the end of the second year, no differences in marketable plants were observed.

In the tree nursery trial, tree rootstock vigor was reduced in plots treated with 1,3-D followed by metam sodium and

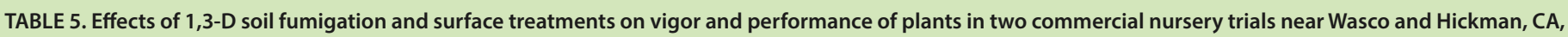
2007-2010

\begin{tabular}{|c|c|c|c|c|c|c|c|c|c|c|c|c|c|c|}
\hline \multirow[b]{2}{*}{ Treatment } & \multicolumn{10}{|c|}{ Rose nursery, 2007-2010 } & \multicolumn{4}{|c|}{ Tree nursery, 2008-2010 } \\
\hline & \multicolumn{2}{|c|}{$\begin{array}{c}\text { 'Dr. Huey' } \\
\text { rootstock } \\
\text { vigor* } \\
8 / 29 / 08\end{array}$} & \multicolumn{2}{|c|}{$\begin{array}{c}\text { 'Home Run' rose } \\
\text { vigor } \\
8 / 29 / 08\end{array}$} & \multicolumn{2}{|c|}{$\begin{array}{c}\text { Marketable } \\
\text { 'Home Run' } \\
\text { plants† } \\
1 / 28 / 09\end{array}$} & \multicolumn{2}{|c|}{$\begin{array}{c}\text { 'Dr. Huey' } \\
\text { rootstock vigor } \\
10 / 16 / 09\end{array}$} & \multicolumn{2}{|c|}{$\begin{array}{c}\text { Marketable } \\
\text { 'Dr. Huey' } \\
\text { rootstock } † \\
2 / 03 / 10\end{array}$} & \multicolumn{2}{|c|}{$\begin{array}{c}\text { Tree } \\
\text { rootstock vigor } \\
5 / 09 / 09\end{array}$} & \multicolumn{2}{|c|}{$\begin{array}{c}\text { Rootstock trunk } \\
\text { caliper } \\
4 / 07 / 10\end{array}$} \\
\hline & \multicolumn{4}{|c|}{........... 1-7 scale..$\ldots \ldots \ldots \ldots$} & \multicolumn{2}{|c|}{ No./90 ft row } & \multicolumn{2}{|c|}{$\ldots \cdot 1-7$ scale...} & \multicolumn{2}{|c|}{ No./90 ft row } & \multicolumn{2}{|c|}{...1-7 scale.... } & \multicolumn{2}{|c|}{$\cdots \cdots m m \cdots$} \\
\hline Untreated & 4.5 & $A \neq$ & 4.3 & $\mathrm{a}$ & 60.0 & $\mathrm{a}$ & 4.3 & a & 94.7 & $a b$ & 2.3 & C & 19.2 & a \\
\hline Methyl bromide & 4.8 & a & 5.0 & a & 66.3 & a & 4.3 & $a b$ & 101.5 & $a b$ & 5.8 & a & 22.2 & a \\
\hline 1,3-D dual application & 4.8 & a & 4.6 & a & 57.5 & a & 3.9 & $a b$ & 103.1 & $b$ & $-\S$ & & - & \\
\hline 1,3-D (HDPE) film & 5.1 & a & 4.8 & a & 55.0 & a & 4.0 & $a b$ & 96.8 & $a b$ & 4.2 & $a b$ & 19.2 & $\mathrm{a}$ \\
\hline 1,3-D (VIF) & 5.1 & a & 5.3 & $\mathrm{a}$ & 59.4 & a & 4.5 & a & 89.1 & $\mathrm{a}$ & 4.2 & $a b$ & 23.0 & $\mathrm{a}$ \\
\hline $\begin{array}{l}1,3-D \text { followed by metam } \\
\text { sodium }\end{array}$ & 2.5 & $b$ & 2.0 & $\mathrm{~b}$ & 21.9 & $\mathrm{~b}$ & 3.5 & $\mathrm{~b}$ & 96.5 & $a b$ & 3.6 & bc & 21.6 & $\mathrm{a}$ \\
\hline 1,3-D (water seals) & 4.0 & $\mathrm{a}$ & 4.3 & $\mathrm{a}$ & 55.6 & a & 3.5 & $\mathrm{~b}$ & 93.6 & $a b$ & 3.2 & bc & 21.2 & $\mathrm{a}$ \\
\hline \multicolumn{15}{|c|}{$\begin{array}{l}\text { † One row of the dormant nursery stock from each plot was harvested and graded according to commercial standards. Marketable roses included the own-rooted 'Home Run' roses or unbudded 'Dr. Huey' rootstock } \\
\text { plants graded as \#1 size with no visual root or cane defects. }\end{array}$} \\
\hline
\end{tabular}


1,3-D with intermittent water seals compared with the other fumigation treatments, but rootstock caliper at the end of the first growing season did not differ among treatments.

\section{Continuing challenges}

Compared with some other fumigation-dependent industries, perennial fruit
Adoption of methyl bromide alternatives, where they exist, in the perennial crop nursery industry will ultimately be driven by state and federal regulations and economics. Although it's heavily regulated, 1,3-D is a viable alternative for growers with coarse-textured soil, but if 1,3-D becomes more difficult to use due to shortages or increasingly stringent

\section{The cost of producing perennial nursery stock using more expensive, laborious or economically risky production methods... could have long-term impacts on the nursery, orchard, vineyard and ornamental industries.}

and nut nursery stock production systems face a more difficult transition to methyl bromide alternatives (Zasada, Walters et al. 2010). Despite several years of research, the following significant challenges to widespread adoption of alternatives in the perennial crop nursery industry remain: (1) National and international market expectations for nematode-free nursery stock limit nursery stock producers to alternatives with very high nematode efficacy at significant depths in the soil. (2) To meet California nursery certification requirements, producers are required to use approved fumigant treatments or conduct a postproduction inspection. A failed inspection may result in an essentially nonsalable crop. (3) Most alternative treatment schedules are based on the use of 1,3-D (with or without chloropicrin), a fumigant that faces its own serious and evolving regulatory issues in California. (4) No currently available alternative fumigant can be used in California to meet certification requirements in nurseries with fine-textured soil at registered rates. (5) Methyl iodide, the alternative fumigant with performance most similar to methyl bromide, is not currently registered in the United States due to a voluntary withdrawal by the manufacturer. (6) Concerns over control of weeds and fungal and bacterial pathogens in the short and long term may further limit adoption of alternatives with a narrower pest control spectrum. (7) Containerized nursery stock production systems are being used in some parts of the industry, but the production costs, market acceptance and long-term viability of this system have not been addressed at the required scale. regulations, it may be only a short-term solution. No viable fumigant alternatives exist for California nurseries with fine-textured soil, and some of them may be unable to produce certified nursery stock in the absence of methyl bromide. The cost of producing perennial nursery stock using more expensive, laborious or economically risky production methods will ultimately be passed on to customers and could have long-term impacts on the

\section{References}

[CDFA] California Department of Food and Agriculture. 2011. Approved treatment and handling procedures to ensure against nematode pest infestation of nursery stock. Nursery Inspection Procedures Manual, Item 7. www.cdfa.ca.gov/phpps/PE/Nursery/pdfs/NIPM_7.pdf (accessed May 8, 2013).

Fennimore SA, Ajwa HA. 2011. Totally impermeable film retains fumigants, allowing lower application rates in strawberry. Calif Agr 65:211-5.

Gao S, Hanson BD, Qin R, et al. 2011. Comparisons of soil surface sealing methods to reduce fumigant emission loss. J Environ Qual 40:1480-7.

Gao S, Wang D. 2011. Vapor flux measurements: Chamber methods. Chapter 9. In: Saponaro S, Sezenna E, Bonomo L (eds.). Vapor Emission to Outdoor Air and Enclosed Spaces for Human Health Risk Assessment: Site Characterization, Monitoring and Modeling. New York: Nova Science Publishers.

Hanson BD, Gerik JS, Schneider SM. 2010. Effects of reduced rate methyl bromide applications under conventional and virtually impermeable plastic film in perennial crop field nurseries. Pest Manag Sci 66:892-9. Hanson BD, Schneider SA. 2008. Evaluation of weed control and crop safety with herbicides in open field tree nurseries. Weed Technol 22:493-8.

Hanson BD, Shrestha A. 2006. Weed control with methy bromide alternatives: A review. CAB Reviews: Perspectives in Agriculture, Veterinary Science, Nutrition, and Natural Resources. 2006 1, No. 063.

Jhala AJ, Gao S, Gerik JS, et al. 2011. Effects of surface treatments and application shanks on nematode, pathogen and weed control with 1,3-dichloropropene. Pest Manag Sci 68:225-30. nursery, orchard, vineyard and ornamental industries.

B.D. Hanson is Cooperative Extension Specialist, University of California, Davis; S. Gao is Research Soil Scientist, USDA-ARS; J. Gerik is Research Plant Pathologist, USDA-ARS; R. Qin is Project Scientist, University of California, Davis; J.A. Cabrera was Postdoctoral Researcher, University of California, Riverside; A.J. Jhala was Postdoctoral Researcher, University of California, Davis; M.J.M. Abit was Postdoctoral Researcher, University of California, Davis; D. Cox is CEO and General Manager, L.E. Cooke Compnay; $B$. Correiar is Breeder and Product Development Manager, Golden State Bulb Growers; D. Wang is Research Leader and Soil Scientist, USDA-ARS; and G.T. Browne is Research Plant Pathologist, USDA-ARS.

This project was primarily supported by the USDA-ARS Pacific Area-Wide Pest Management Program for Integrated Methyl Bromide Alternatives. Funding from the Fruit Tree, Nut Tree, and Grapevine Improvement Advisory Board and in-kind support from Weeks Rose Nursery, Dave Wilson Nursery, TriCal Inc., and Dow AgroSciences for these projects is acknowledged. The technical support of Stella Zambrzuski, Nancy Goodell, Jim Gartung, Patty Mungur, Robert Shenk, Aileen Hendratna and other USDA-ARS Water Management Research Unit staff is also appreciated.
McKenry MV, Buessing D, Williams K. 2003. New chisel shanks enable improved fumigation of finer-textured soils. Proc Ann Int Res Conf on Methyl Bromide Alternatives and Emissions Reductions. San Diego, CA, Oct. 31-Nov. 3, 2003. p 36-1-3.

Schneider SM, Hanson BD. 2009. Effects of fumigant alternatives to methyl bromide on pest control in a deciduous fruit and nut plant nursery. HortTechnol 19:526-32.

Schneider SM, Hanson BD, Gerik JS, et al. 2009. Comparison of shank- and drip-applied methyl bromide alternatives in perennial crop field nurseries. HortTechnol 19:331-9.

Shrestha A, Browne GT, Lampinen BD, et al. 2008. Perennial crop nurseries treated with methyl bromide and alternative fumigants: Effects on weed seed viability, weed densities, and time required for hand weeding. Weed Technol 22:267-78.

[US EPA] United States Environmental Protection Agency. 2010. Critical Use Exemption Information. www. epa.gov/ozone/mbr/cueinfo.html.

US EPA. 2012. Soil Fumigant Regulatory Background. www.epa.gov/oppsrrd1/reregistration/soil_fumigants/ soil-fum-reg-backgrnd.html.

Zasada IA, Halbrendt JM, Kokalis-Burelle N, et al. 2010. Managing nematodes without methyl bromide. Annu Rev Phytopathol 48:15.1-18.

Zasada IA, Walters TW, Hanson BD. 2010. Challenges in producing nematode- and pathogen-free fruit and nut nursery crops in the United States. Outlook Pest Manag 21:246-50. 